\title{
Estimating the Characteristics of Runoff Inflow into Lake Gojal in Ungauged, Highly Glacierized Upper Hunza River Basin, Pakistan
}

\author{
Shiqiang Zhang* (张世强) \\ Qilian Shan Station of Glaciology and Ecologic Environment, Cold \& Arid Regions Environmental \& Engineering \\ Research Institute, Chinese Academy of Sciences, Lanzhou 730000, China; State Key Laboratory of Cryospheric \\ Science, Cold \& Arid Regions Environmental \& Engineering Research Institute, \\ Chinese Academy of Sciences, Lanzhou 730000, China \\ Min Xu (许民), Junli Xu (许君利), Qiudong Zhao (赵求东) \\ State Key Laboratory of Cryospheric Science, Cold \& Arid Regions Environmental \& Engineering \\ Research Institute, Chinese Academy of Sciences, Lanzhou 730000, China \\ Stefan Hagemann \\ Max Planck Institute for Meteorology, Bundesstraße 53, D-20146, Hamburg, Germany
}

\begin{abstract}
Motivated by the potential flood outburst of Lake Gojal in the ungauged highly glacierized (27\%) upper Hunza River Basin (HRB) in Pakistan that was dammed by a massive landslide on 4 January 2010, we attempt to analyze the characteristics of water inflow to the lake employing remote sensing data, two hydrological models, and sparsely observed data. One of the models (Model I) is a monthly degree-day model, while another (Model II) is the variable infiltration capacity (VIC) model. The mixture of glacier runoff output from Model I and runoff over unglacierized areas calculated by Model II has a similar seasonal variation pattern as that estimated from data recorded at a downstream station. This suggests that glacier runoff is the main source $(87 \%)$ of runoff inflow into the lake. A sensitivity analysis suggests that the water inflow to the lake is highly sensitive to an increase in air temperature. Runoff in May is predicted to sharply increase by $15 \%$ to more than two-fold if the air temperature increases by 1 to $7{ }^{\circ} \mathrm{C}$, but it is predicted to increase only from $9 \%$ to $34 \%$ if the precipitation increases by $10 \%$ to $40 \%$. The results suggested that the water inflow into Lake Gojal will not sharply

This study was supported by the Global Change Research Program of China (No. 2010CB951404), and the National Natural Science Foundation of China (Nos. 41030638, 41121001).

(C) China University of Geosciences and Springer-Verlag Berlin

rise even if there is heavy rain, and it needs to be in caution if the air temperature sharply increases. Analysis on long-term air temperature record indicates that the water inflow into the lake in May 2010 was probably less than average owing to the relatively low air temperature. Consequently, the flood outburst did not occur before the completion of the spillway on 29 May 2010.

KEY WORDS: ungauged, glacierized, runoff modeling, sensitivity analysis.
\end{abstract}

*Corresponding author: zhangsq@1zb.ac.cn Heidelberg 2013

Manuscript received December 23, 2011.

Manuscript accepted February 20, 2012. 


\section{INTRODUCTION}

A massive landslide outburst took place at Sarat, Attabad, Pakistan, on 4 January 2010. The landslide was a major disaster and directly killed 20 people and left many homeless. It blocked the main stream of Hunza River and formed the landslide-dammed Lake Gojal. The daily water level in Lake Gojal was continuously increasing until May 2010. It has been more than $14.3 \mathrm{~km}$ long around 4 May 2010 as derived from Advanced Spaceborne Thermal and Reflection Radiometer (ASTER) image, and the Karakorum Highway was completely inundated by the Lake Gojal, which is a regionally critical land link between Pakistan and China. The potential outburst flood of Lake Gojal would affect not only the wellbeing of those living downstream of Hunza River Basin in Pakistan but also the commerce and relations between nations if the dam failure occurs (Kargel et al., 2010). Thus, estimating the runoff input to Lake Gojal is critical to the evaluation and management of a potential flood.

The latest possible date for completing and widening the spillway constructed by the Pakistan government was on 24 May 2010. However, the observed water level of Lake Gojal has sharply increased by about $10.0 \mathrm{~m}$ from 2 May to 16 May. The potential outburst flood had received much international attention. On 14 May 2010, the weather forecast was 61 $\mathrm{mm}$ snow and $44 \mathrm{~mm}$ rain in the forthcoming week, which increased the worrying about the failure of natural rock dam in advance. The characteristics of runoff inflowing into Lake Gojal are key considerations for decision makers evaluating the safety of the dam and the progress of widening the spillway and managing the potential outburst flood risks.

The areas above the Lake Gojal are parts of the upper reach of Hunza River Basin (HRB). Archer (2003) suggested that summer runoff of HRB above Dainyor Station has a strong correlation with summer air temperature, which indicates that the river runoff probably also has a strong relationship with glacier melt water. Wang et al. (2011) suggested that river runoff of three different glacier-covered catchments in eastern Tianshan exhibit distinctive trends. Thus, it is reasonable to apply hydrological models, which include glacier meltwater to estimate the water inflow into the lake. Unfortunately, it was difficult to directly and continuously monitor the water input to the lake. The observed daily inflows were available only on 2, 12, and 16 May. Thus, we need to simulate the water input to the lake by using hydrological models with sparse hydrological data, remote sensing data, digital elevation models (DEM), and topographic maps.

We present the results of modeling the input to the dammed lake by applying two hydrological models. One model is the monthly degree-day model, another model is the variable infiltration capacity hydrological model. The characteristics of river runoff, the sensitivity of the river runoff to air temperature and precipitation, and the potential change of the inflow under the forthcoming $105 \mathrm{~mm}$ precipitation forecast on 14 May 2010 are estimated.

\section{DATA AND METHODS}

\section{Study Area}

HRB is situated in the high Karakoram range at longitude $74^{\circ} 03^{\prime} \mathrm{E}$ to $75^{\circ} 48^{\prime} \mathrm{E}$ and latitude $36^{\circ} 04^{\prime} \mathrm{N}$ to $37^{\circ} 06^{\prime} \mathrm{N}$ in northern Pakistan (Fig. 1) and is close to the Yarkant River Basin of China. The basin area above the Lake Gojal is $9056 \mathrm{~km}^{2}$ as determined from the DEM of the Shuttle Radar Topography Mission (SRTM-3) data with $90 \mathrm{~m}$ resolution. The total area of glaciers is $2402.3 \mathrm{~km}^{2}$ (27\%) according to a glacier inventory based on $1: 100000$ topographic maps for the period 1976-1980.

\section{Data}

Two DEMs were used in this study. The SRTM DEM was used to derive the basin information and for hydrological modeling. The ASTER DEM with a resolution of $30 \mathrm{~m}$ was used to analyze the area-volume relationship of Lake Gojal.

The rates of the lake level rise, depth, and extended length, seepage at six sites on the dam were obtained from in-situ observations only in three days. The observed daily water inflow was 53.1, 70.8, and $70.8 \mathrm{~m}^{3} \mathrm{~s}^{-1}$ on 2,12 , and 16 May 2010 , respectively. The monthly average hydrological data of the downstream Dainyor Station during 1966 to 1997 were refer from Archer (2003), where Dainyor Station has a basin area of $13925 \mathrm{~km}^{2}$. One ASTER image of the HRB acquired on 16 March was used to visually compare the extent of the lake with that estimated 


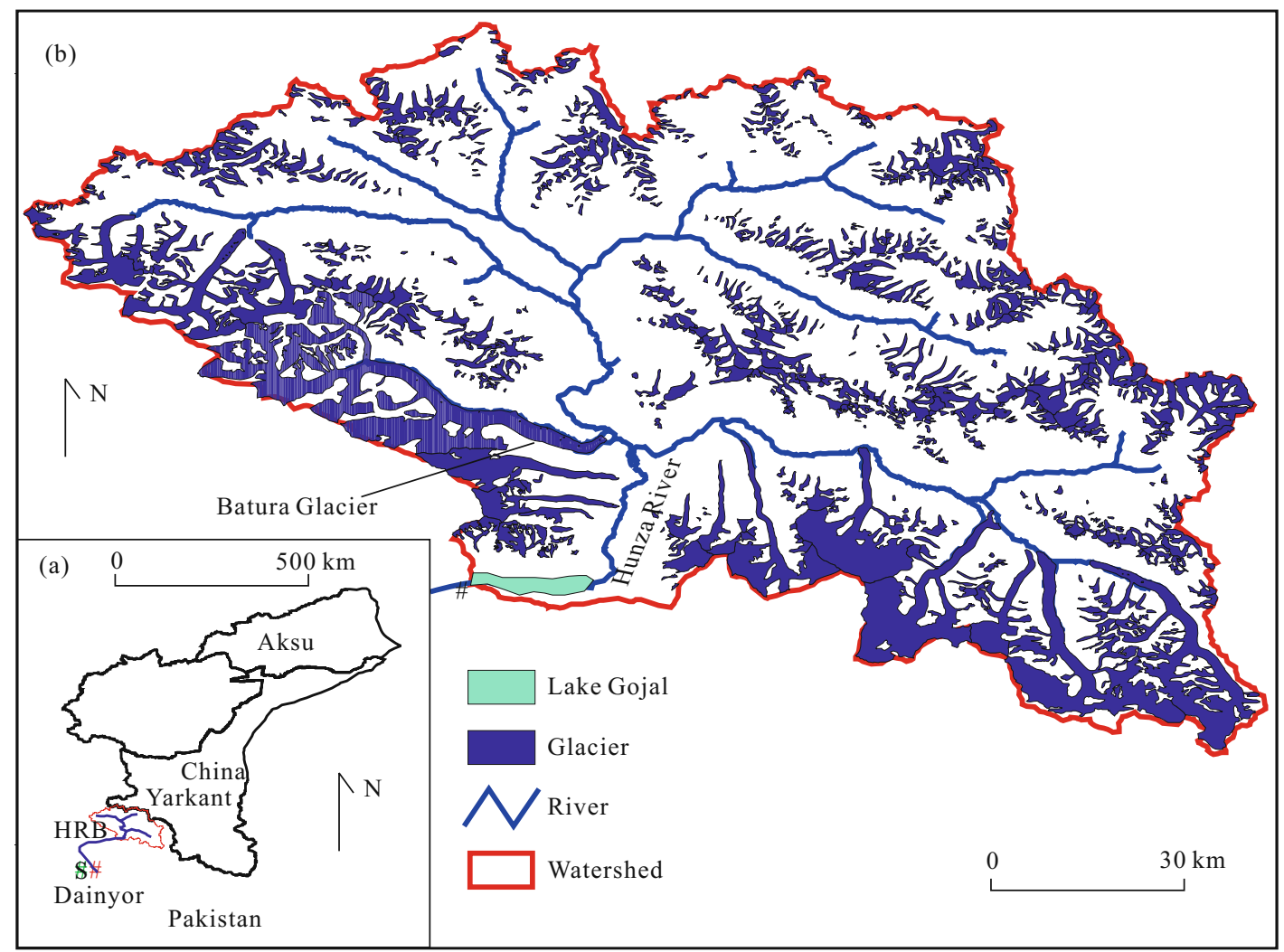

Figure 1. Location of Lake Gojal in the upper reach of Hunza River Basin (HRB). The Lake Gojal was formed on 4 January 2010 after a massive landslide at Sarat, Attabad, Pakistan.

from observed data and DEM, and the lake levelvolume relationship of Lake Gojal was estimated.

There are no meteorological stations in HRB. The air temperature was determined from Chinese national meteorological observations. Two precipitation datasets were used. One was daily data derived from the Asian Precipitation-Highly-Resolved Observational Data Integration towards evaluation of water resources (APHRODITE, http://www.chikyu.ac.jp/ precip/products/index.html) for 1970 to 2007 , with a spatial resolution of $0.25^{\circ}$, and the other was monthly precipitation data for 1961 to 2006 interpolated from neighboring Chinese national meteorological stations. As these datasets did not have the data for 2010, the runoff characteristics were derived from the analysis of simulated series from 1970 to 2007 and the sensitivity analysis.

\section{Modified Monthly Degree-Day Model (Model I)}

A degree-day factor summarizes the complex interaction among various energy components on a glacier (Hock, 2005). The degree-day model assumes a relationship between ablation and local air tempera- ture expressed in the form of positive temperature sums. Wu et al. (2011) implied that mass balances simulated by the degree-day model are in good agreement with the observations in Urumqi Glacier No. 1, eastern Tianshan, China. One modified monthly degree-day model (Zhang et al., 2012a) was developed and has been successfully applied in estimating the long-term change of glacier melt water in the neighboring Tarim interior Basin of China (Zhang et al., 2012b; Gao et al., 2010). This also was used to simulate glacier runoff in the present study (Model I). The annual mass balance was calculated from the simulated snow accumulation and the snow and ice melt. The glacier runoff is the sum of rain directly flowing out and the melting of snow and ice minus the refreezing parts. Model I runs in elevation bands with the extent of $100 \mathrm{~m}$. The degree-day factors of snow and ice were adjusted by comparing the simulated mass balance and runoff depth with short-term observations and literature values.

The monthly precipitation data were interpolated from data recorded at Chinese national stations with elevation gradients dependent based on short-term 
observations in the area of the Batura Glacier (Liu, 1980). The monthly precipitation gradients were low

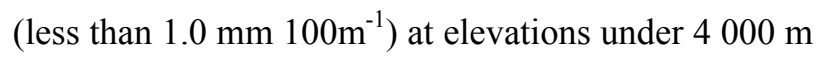
and high at elevations above $4000 \mathrm{~m}$ a.s.l. (Table 1), especially in summer, where the gradient exceeds 10.0 $\mathrm{mm} 100 \mathrm{~m}^{-1}$. Monthly surface air temperature lapse rates are calculated from the data recorded by neighboring meteorological stations in western China. Except in May and June, the air temperature lapse rate (Table 2) was less than $0.6{ }^{\circ} \mathrm{C} 100 \mathrm{~m}^{-1}$, which is lower than the rates of 0.65 to $0.75{ }^{\circ} \mathrm{C}_{100 \mathrm{~m}^{-1}}$ recorded at nine Karakoram stations ranging in elevation from 1000 to $4700 \mathrm{~m}$ a.s.l. (Archer, 2003).

Table 1 Monthly precipitation gradients in the Hunza River Basin (mm 100m

\begin{tabular}{ccccccccccccc}
\hline Month & 1 & 2 & 3 & 4 & 5 & 6 & 7 & 8 & 9 & 10 & 11 & 12 \\
\hline$<4000$ m a.s.1. & -0.1 & -0.1 & -0.1 & -0.2 & -0.4 & -0.6 & -0.5 & -0.3 & -0.2 & -0.1 & -0.1 & -0.1 \\
$>4000$ m a.s.1. & 2.9 & 3.4 & 2.9 & 5.3 & 11.1 & 17.8 & 13.9 & 10.9 & 7.2 & 7.8 & 0.7 & 2.2 \\
\hline
\end{tabular}

Table 2 Monthly temperature lapse rates in the Hunza River Basin $\left({ }^{\circ} \mathrm{C} 100 \mathrm{~m}^{-1}\right)$

\begin{tabular}{lllllllllllll}
\hline Month & Jan. & Feb. & Mar. & Apr. & May & Jun. & Jul. & Aug. & Sep. & Oct. & Nov. & Dec. \\
\hline & 0.29 & 0.39 & 0.48 & 0.58 & 0.61 & 0.63 & 0.59 & 0.56 & 0.53 & 0.47 & 0.43 & 0.31 \\
\hline
\end{tabular}

Other parameters of Model I were set to values calibrated in the neighboring Tarim River Basin (Gao et al., 2010). The threshold temperatures for liquid precipitation and solid precipitation were 2.0 and $0.5^{\circ} \mathrm{C}$, respectively. The refreezing rate was set to 0.1 . The snow and glacier degree-day factors were tuned with observations made on the Batura Glacier in the HRB during 1974-1975 (Shi and Zhang, 1984). The final degree-day factors of ice and snow were set to 5.2 and $3.1 \mathrm{~mm} \mathrm{~d}^{-1}{ }^{\circ} \mathrm{C}^{-1}$, respectively.

The observed equilibrium line for the Batura Glacier ranged from 4700 to $5300 \mathrm{~m}$ a.s.l. and had an average height of $5000 \mathrm{~m}$ a.s.l. (Shi and Zhang, 1984). The altitude of the simulated equilibrium line in the HRB was $5050 \mathrm{~m}$ a.s.1. for the period 1974-1975. The observed glacier runoff for the Batura Glacier was $1400-1800 \mathrm{~mm}$ for the period 1974-1975, whereas the simulated runoff was $1270 \mathrm{~mm}$. These comparisons indicate that the simulation of glacier mass balance and meltwater is reasonable so that the model can be used to estimate the glacier runoff of HRB.

\section{Modified VIC Model (Model II)}

The VIC model (Cherkauer and Lettenmaier, 2003; Liang et al., 1996, 1994) has been successfully applied to many large basins, including cold regions, such as pan-Arctic land region (Su et al., 2006, 2005), and the model also offers a great potential for enlight- enment regarding large-scale hydrology in poorly observed region (Slater et al., 2007). One glacier module was recently developed on the basis of the energy balance at the glacier-atmosphere interface. It was successfully applied to the Aksu River Basin after it had been calibrated with hydrological data (Zhao et al., 2011). The main characteristics of the new module include the representation of meteorological elements based on elevation difference between the glacier area in the grid and the neighbor grids, considering the effects of slope and aspect on solar radiation, and a mass balance model following Kloke and Oerlemans (2002). The routing scheme employs an algorithm coupled with the VIC model (Lohmann et al., 1998, 1996).

The input land-use data were derived from the University of Maryland, 1-km Global Land Cover dataset (http://www.geog.umd.edu/landcover $/ 1 \mathrm{~km}$ map.html). Bare land and shrubs occupy about $62 \%$ and $11 \%$ of the basin, respectively, and other land-use types account for less than $1 \%$ of the basin. The soil data were extracted from the Global Soil Data Products developed by the International GeosphereBiosphere Programme Data and Information System (IGBP-DIS).

The VIC model was run at 0.083 -degree (about $10 \mathrm{~km}$ ) resolution with daily time steps in full energy balance mode forced with daily precipitation from APHRODITE data. The spatial resolution is same as 
that applied in the Aksu River Basin, and the resolution is close to that of the soil data. The daily maximum and minimum temperatures and wind speed were derived from Chinese national meteorological stations near the HRB. As there are no data available for a direct calibration of the model, the model parameters were adopted to the values calibrated with hydrological data in the Aksu River Basin (Zhao et al., 2011), which is about $400 \mathrm{~km}$ northeast of the HRB.

\section{RESULTS}

\section{Comparison of Simulated Runoff to Observed Runoff at Dainyor Station}

The monthly meltwater above glacierized areas was calculated by the models I and II, and the runoff above unglacierized areas was simulated by Model II for 1970 to 2007. The mixture runoff that was calculated from the sum of the meltwater of glacierized area of Model I and the runoff of the unglacierized area. As there is no observed hydrological data available to validate the model, the simulated monthly average runoff from Model II, which include runoff over glacierized areas and unglacierized areas, and the mixture runoff from 1970 to 1997 were compared to that estimated from the observed hydrological data at the downstream Dainyor Station (Fig. 2). Both the simulated runoff from Model II and the mixture runoff have a monthly and seasonal variation pattern similar to that observed at Dainyor Station, but the simulated runoffs are lower than the observed one. The mixture runoff has less discrepancy with the observed, so it is taken to represent the runoff inflow into Lake Gojal. The underestimation in both simulated runoff in all seasons indicates that the forcing precipitation of the basin is probably underestimated, which seems to be influenced by orographic effects in the HRB.

There is a greater uncertainty about the seasonality and magnitude of precipitation in Karakoram regions. Wake (1989) suggested the possibility that there is a higher proportion of annual precipitation during the monsoon season at higher elevations. Not only precipitation intensity but also the frequency of precipitation are different from lowland to Alpine areas (Ding, 1991). There is a five- to ten-fold increase in precipitation from the glacier terminal to the elevation of maximum precipitation at 5000-6 $000 \mathrm{~m}$ a.s.l.

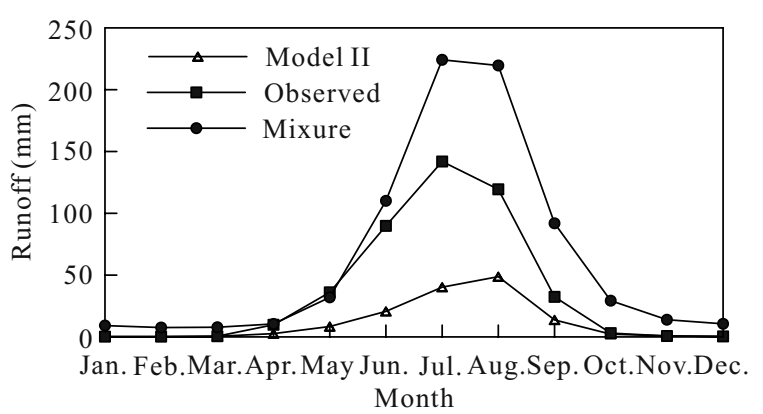

Figure 2. Simulated monthly average runoff $(\mathrm{mm})$ by using Model II, the mixture ( $\mathrm{mm}$ ) of meltwater simulated by Model $I$ and runoff in the unglacierized area simulated by Model II during 1970 to 1997, and runoff observed (Archer, 2003) at Dainyor Station during 1966 to 1997 in Hunza River Basin.

(Hewitt, 2007). This is illustrated by the observed annual precipitation at the Batura Glacier during 1974-1975, which was $1300-1500 \mathrm{~mm}$ near the equilibrium line at $5000 \mathrm{~m}$ a.s.l., while in the valley below at $3000 \mathrm{~m}$ a.s.l., it was only about $100 \mathrm{~mm}$ (Liu, 1980).

There is no meteorological station in HRB, and the HRB covers elevation bands from 2000 to 7700 $\mathrm{m}$ a.s.1.. Therefore, the great precipitation gradients and the wider elevation ranges indicate that it is difficult to accurately represent precipitation in the forcing of a hydrological model. Although we use the precipitation data from two different sources in models I and II and the monthly precipitation gradients were considered, there are still many uncertainties in estimating the precipitation.

\section{Characteristic of Simulated Runoff}

The contribution of glacier runoff to the total runoff simulated using Model II is 56\% (Fig. 3a), and the maximum monthly runoff is $640.0 \mathrm{~m}^{3} \mathrm{~s}^{-1}$ in August 2006, which indicates that glacier runoff is the main component of runoff in HRB, especially in summer. The runoff in the unglacierized area has significantly increased since 2003, which is also same with the total runoff. However, there is some uncertainty occurs in the precipitation forcing because the number of stations involved in the production of the APHRODITE dataset has probably changed around 2003 (Yatagai et al., 2009). 

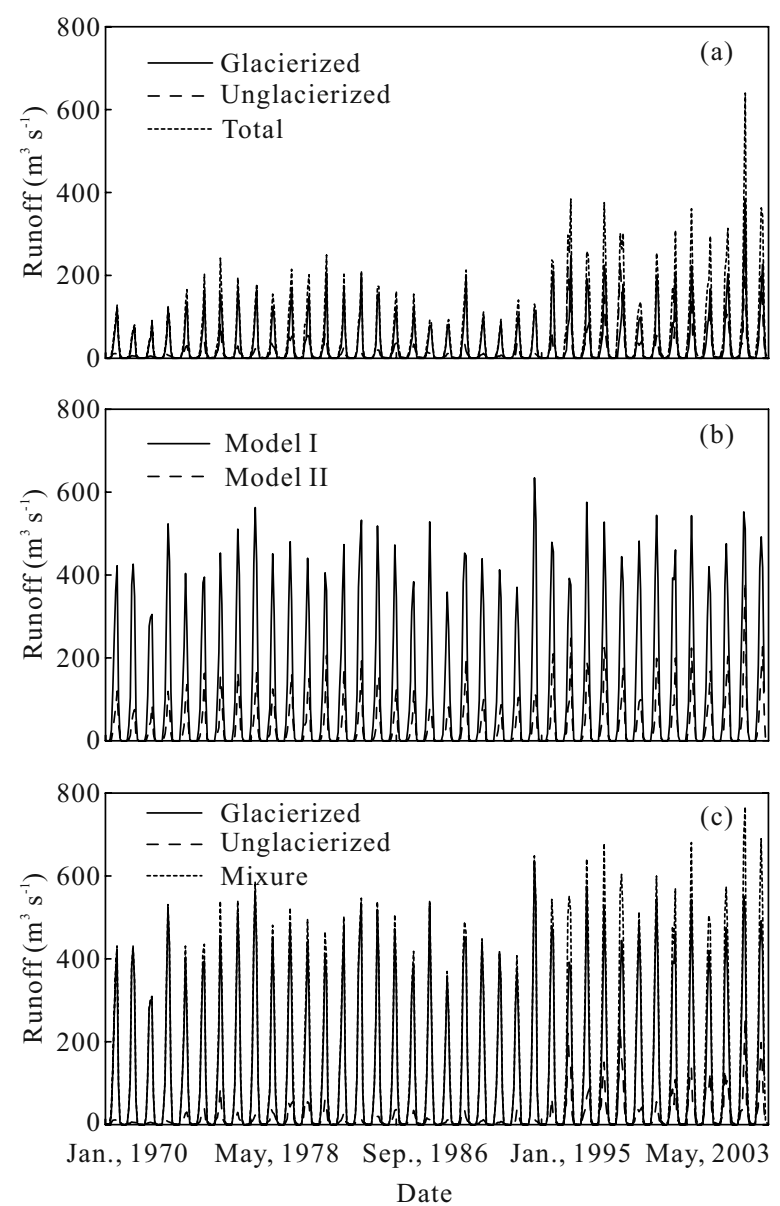

Figure 3. Runoff $\left(\mathrm{m}^{3} \mathrm{~s}^{-1}\right)$ in the glacierized, unglacierized, and total areas simulated by Model II (a), glacier meltwater $\left(\mathrm{m}^{3} \mathrm{~s}^{-1}\right)$ simulated by Model I and Model II (b), glacier runoff $\left(\mathrm{m}^{3} \mathrm{~s}^{-1}\right)$ simulated by Model I, runoff $\left(\mathrm{m}^{3} \mathrm{~s}^{-1}\right)$ of unglacierized area simulated by Model II, and the mixture $\left(\mathrm{m}^{3} \mathrm{~s}^{-1}\right)$ of meltwater simulated by Model $I$ and runoff in the unglacierized area simulated by Model II (c) in Hunza River Basin during 1970 to 2007.

The meltwater simulated using Model II is far less (27.9\%) than that simulated by Model I (Fig. 3b). There are two likely reasons for this. One is the large underestimation of precipitation due to the large precipitation gradients. Another reason is that different elevations were used in the precipitation forcing of models I and II. The forcing precipitation of Model I calculated based on elevation bands method, while that of Model II is calculated based on the differences of the average elevation of the grid box and the average elevation of the grid in the meteorological station located in. In the alpine areas, there are always great elevation variations among peaks and deep channels in one grid, while the differences between average elevations of grid boxes are relatively smaller, which led to the forcing precipitation of Model I to be greater than that of Model II.

The monthly glacier runoff is highest in July for Model I, while the highest runoff occurs in August for Model II. This is probably because of two reasons. One is the uncertainty in July and August precipitation of APHRODITE. Another reason is probably the estimated delay time of the runoff routing in Model II is longer than the observed one.

The average contribution of glacier runoff to the mixture runoff is $87 \%$ during 1970 to 2007 (Fig. 3c). The runoff was concentrated in the melt season from May to August, which comprised $88 \%$ of the annual. The maximum runoff occurred in August 2006. The runoff sharply increases from April to May, which indicates that May is the onset of the melt season, and the runoff in May is probably highly dependent on the air temperature warming.

\section{Sensitivity}

Considering that the annual runoff and seasonal distribution in 2004 is close to the simulated average runoff during 1970 to 2007, we used the simulated runoff in 2004 to investigate the runoff response to a rapid increase in precipitation and air temperature by a sensitivity analysis. Here, period of 2002 to 2003 was selected as spin-up period of the model. Such an investigation is critical to predict the potential changes in runoff following weather forecasts such as that made on 14 May 2010.

The monthly runoffs both increases in glacierized areas and unglacierized areas when precipitation increases by $10 \%, 20 \%, 30 \%$, and $40 \%$ (Fig. 4, Table 3). There is no remarkable increase in the runoff over the glacierized areas except in July and August in the melt season, even when the precipitation increases by $40 \%$ (Fig. 4a). In August, the peak glacier runoff is predicted to increase only by $12 \%$ as the precipitation increases by $40 \%$. The runoff over the unglacierized areas is predicted to significantly increase from April to October (Fig. 4b), and the peak runoff in August is predicted to increase by $38 \%$ as the precipitation increases by $40 \%$. As a consequence, the total runoff is predicted to generally increase as the precipitation 

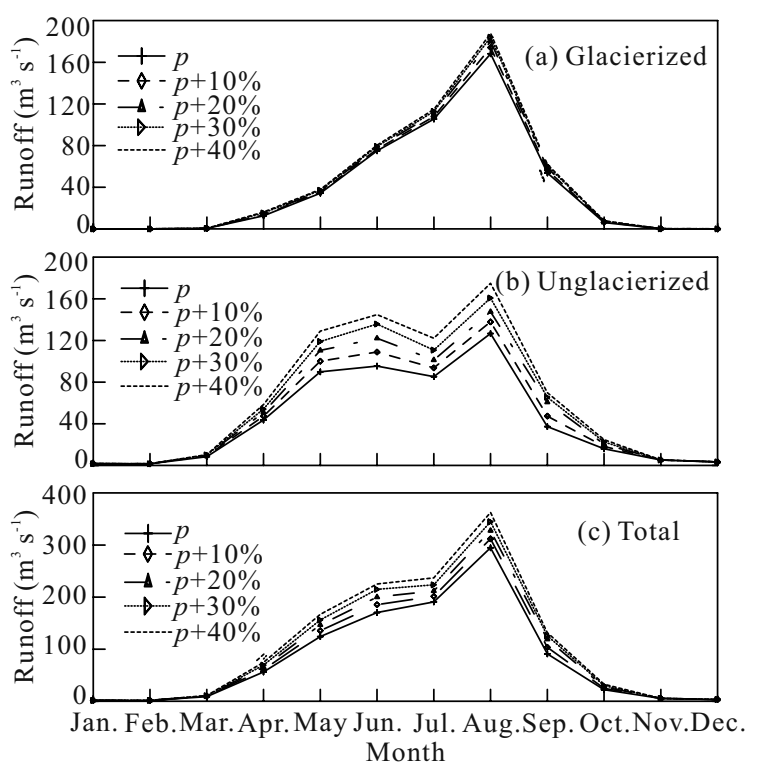

Figure 4. Monthly runoff $\left(\mathrm{m}^{3} \mathrm{~s}^{-1}\right)$ in the (a) glacierized, (b) unglacierized, and (c) total areas if precipitation increases by $0 \%, 10 \%, 20 \%, 30 \%$, and $\mathbf{4 0 \%}$, respectively, above Lake Gojal in Hunza River Basin.

increases, especially from May to September (Fig. 4c). The runoff in May is predicted to increase from $9 \%$ to $34 \%$ as the precipitation increases from $10 \%$ to $40 \%$.

The monthly runoffs over glacierized areas and unglacierized areas have different sensitivities if monthly air temperature increases by from 1 to $7{ }^{\circ} \mathrm{C}$ (Fig. 5, Table 4). The runoff over the glacierized areas is predicted to significantly increase during the whole summer even if the air temperature increases by only $1{ }^{\circ} \mathrm{C}$ (Fig. 5a). The peak runoff in August is predicted to increase by $32 \%$ as the air temperature increases by $1{ }^{\circ} \mathrm{C}$, and it is predicted to reach more than two fold as the air temperature increases by $7{ }^{\circ} \mathrm{C}$. The runoff in May is predicted to increase by $26 \%$ to more than six-fold as the air temperature increases by 1 to $7^{\circ} \mathrm{C}$, respectively, which indicates that the glacier runoff is very sensitive to air temperature.

The runoff over the unglacierized area has a complex pattern if the air temperature increases. The runoff from October to May is predicted to increase, owing to earlier snow melt and less parts of precipitation falling as snow (Fig. 5b). The runoff in August is predicted to decrease by $15 \%$ to $37 \%$ as the air temperature increases by 1 to $7^{\circ} \mathrm{C}$. As a consequence, the total runoff is predicted to generally increase as the air temperature increases (Fig. 5c), which suggests that the runoff increase due to a melt increase over the glacierized area is far greater than the decrease in the unglacierized area. The total runoff in May is predicted to increase by $14.7 \%$ to more than two fold as the air temperature increases by from 1 to $7{ }^{\circ} \mathrm{C}$, which suggests that also the total runoff is highly sensitive to air temperature. This indicates that the lake level will sharply rise if the air temperature significantly increases.

\section{Comparison of Simulated Average Runoff in May to Observed in May 2010}

The observed water inflows into the lake on 2,12 , and 16 May 2010 were less than the average total runoff of $141.6 \mathrm{~m}^{3} \mathrm{~s}^{-1}$ simulated from 1970 to 2007 and also less than the average runoff in May during 1966 to 1997 estimated from the observation at Dainyor. Our modeling suggests that observed lower stream flow in May 2010 is probably associated with lower air temperature. Cold weather with rain and snow forecast for 14 May 2010 suggests that the air temperature was lower because snow in mid-May is uncommon. Cold weather probably slows the glacial ablation, and the total runoff input to the lake would not sharply increase on 16 May even if there is intense

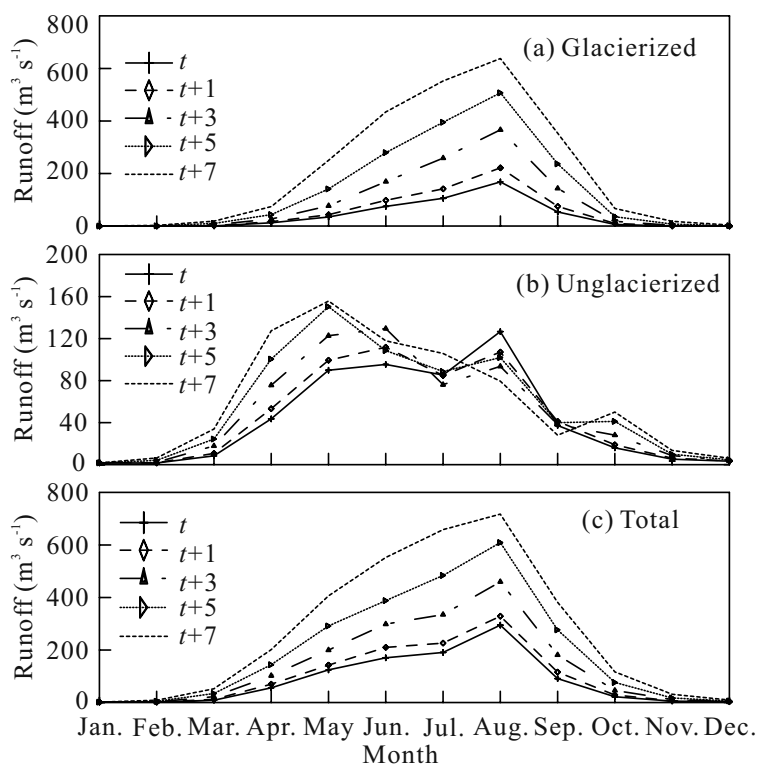

Figure 5. Monthly runoff $\left(\mathrm{m}^{3} \mathrm{~s}^{-1}\right)$ in the (a) glacierized, (b) unglacierized, and (c) total areas if air temperature increases by $0,1,3,5$, and $7{ }^{\circ} \mathrm{C}$, respectively, above Lake Gojal in Hunza River Basin. 


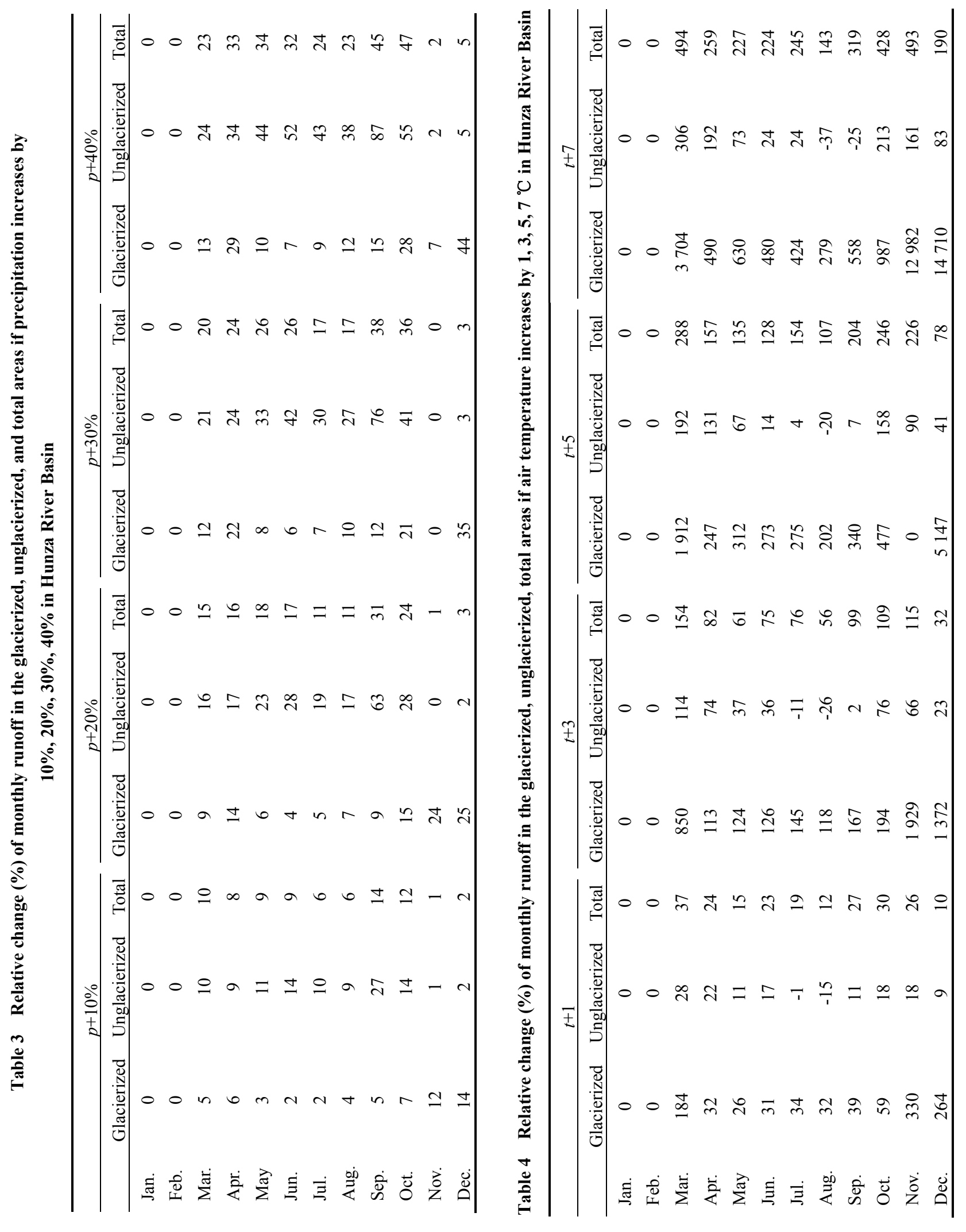


precipitation, which would benefit the completion of the spillway. However, caution must be taken when the weather forecast predicts a significant increase of air temperature.

The monthly air temperature anomalies in May from 1951 to 2010 derived from global gridded monthly anomalies of observed air temperature and combined observed air and marine temperature (HADCRU3) suggest that the anomaly in 2010 is 0.0 ${ }^{\circ} \mathrm{C}$ (Fig. 6). Considering the increase of air temperature since 2000, air temperature in May 2010 is relatively lower. Water in Lake Gojal overtopped the spillway on 29 May 2010, which also proved that the relatively lower air temperature is probably the main reason of observed lower runoff inflow into Lake Gojal.

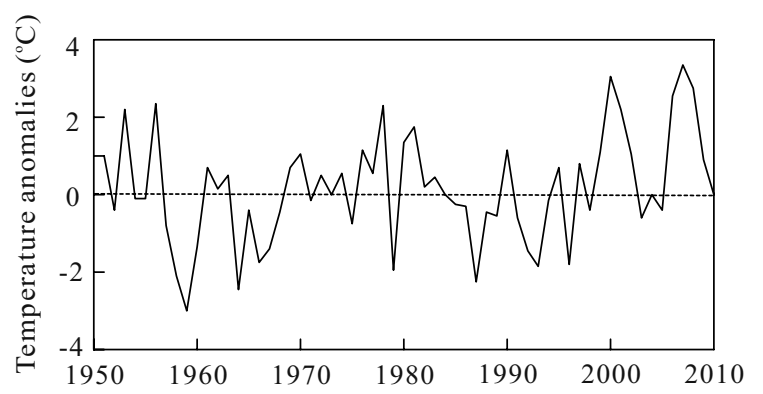

Figure 6. Monthly air temperature anomalies of May in Hunza River Basin during 1951 to 2010 derived from global-gridded $\left(5^{\circ} \times 5^{\circ}\right)$ monthly anomalies of observed air temperature and combined observed air and marine temperatures (HADCRU3).

\section{CONCLUSION AND DISCUSSION}

This study presents an example of the prompt estimation of hydrological characteristics with sparse data in a highly glacierized area when facing a potential disaster. Considering that there are always limited data in alpine areas, this approach can be potentially applied to other highly glacierized basins.

By applying the monthly degree-day model and VIC model, DEMs, observation data for 2010 and 1974/1975, ASTER image in the HRB, some conclusions were drawn.

(1) The mixture of the glacier runoff simulated by the monthly degree-day model and the runoff in the unglacierized area simulated by the VIC model is found to have a monthly variation pattern similar to that estimated from data recorded at the downstream station Dainyor. However, the simulated discharge is lower than the latter. The main reason is probably the underestimation of forcing precipitation gradients of two models in the HRB.

(2) Sensitivity analysis suggests that the total runoff is highly sensitive to air temperature. The water inflow into Lake Gojal in May is predicted to sharply increase by $15 \%$ to more than two-fold if the air temperature increases by 1 to $7{ }^{\circ} \mathrm{C}$, while it is predicted to increase only by $9.1 \%$ to $34.4 \%$ if precipitation increases by $10 \%$ to $40 \%$.

(3) The observed water input to the lake in May 2010 is less than the average, owing to the relatively lower air temperature. Consequently, the total runoff at the 14 May 2010 would not sharply increase even if there is heavy rain occurs. It is the main reason of why the potential flood did not occur before the completion of the spillway on 29 May 2010.

There is great uncertainty in the simulated runoff volumes due to the great variation in the seasonality and magnitude of precipitation in the Karakoram region. Considering that the elevation bands range from 2000 to $7700 \mathrm{~m}$ a.s.l., there needs to be a very high density of meteorological stations to observe the actual precipitation gradients, especially in very high mountain areas around $6000 \mathrm{~m}$ a.s.1.. A highresolution remote-sensing precipitation product will probably help monitor precipitation in the future.

\section{ACKNOWLEDGMENTS}

We used APHRO_MA_V1003R1, which has better quality control, incorporates more data, and has bugs corrected when compared with APHRO_MA V0902 provided by APHRODITE.

\section{REFERENCES CITED}

Archer, D. R., 2003. Contrasting Hydrological Regimes in the Upper Indus Basin. Journal of Hydrology, 274: 198-210

Cherkauer, K. A., Lettenmaier, D. P., 2003. Simulation of Spatial Variability in Snow and Frozen Soil. Journal of Geophysical Research, 108(D22): 8858, doi:10.1029/2003JD 003575

Ding, Y. J., 1991. Precipitation Conditions for the Development of the Present Glaciers. Geo Journal, 25(2/3): 243-248

Gao, X., Ye, B. S., Zhang, S. Q., et al., 2010. Glacier Runoff Variation and Its Influence on River Runoff during 
1961-2006 in the Tarim River Basin, China. Science China Series D: Earth Sciences, 53: 880-891, doi:10. 1007/s11430- 010-0073-4

Hewitt, K., 2007. Tributary Glacier Surges: An Exceptional Concentration at Panmah Glacier, Karakoram Himalaya. Journal of Glaciology, 53(181): 181-188

Hock, R., 2005. Glacier Melt: A Review on Processes and Their Modelling. Progress in Physical Geography, 29(3): $362-391$

Kargel, J. S., Fink, W., Furfaro, R., et al., 2010. Hunza Landslide and Monsoon Flooding in Pakistan Call for International Attention to Transboundary Natural Hazards. American Geophysical Union Fall Meeting 2010. American Geophysical Union, San Francisco, California, USA, Abstract \#NH52A-0

Kloke, E. J., Oerlemans, J., 2002. Model Study of the Spatial Distribution of the Energy and Mass Balance of Morteratschgletscher, Switzerland. Journal of Glaciology, 48(163): 506-518

Liang, X., Lettenmaier, D. P., Wood, E. F., 1994. A Simple Hydrologically Based Model of Land Surface Water and Energy Fluxes for General Circulation Models. Journal of Geophysical Research, 99(D7): 14415-14428

Liang, X., Wood, E. F., Lettenmaier, D. P., 1996. Surface Soil Moisture Parameterization of the VIC-2L Model: Evaluation and Modification. Global and Planetary Change, 13: 195-206

Liu, G., 1980. The Climate of the Batura Glacier and Its Adjacent Areas. In: Lanzhou Institute of Glaciology and Geocryology, Chinese Academy of Sciences, Professional Papers on the Batura Glacier, Karakorum Mountains. Science Press, Beijing. 99-110 (in Chinese)

Lohmann, D., Nolte-Holube, R., Raschke, E., 1996. A Large Scale Horizontal Routing Model to be Coupled to Land Surface Parameterization Schemes. Tellus, 48A: 708-721

Lohmann, D., Raschke, E., Nijssen, B., et al., 1998. Regional Scale Hydrology: I. Formulation of the VIC-2L Model Coupled to a Routing Model. Hydrological Sciences, 43: $131-141$

Shi, Y. F., Zhang, X. S., 1984. Some Studies of the Batura Glacier in the Karakoram Mountains. In: Miller, K. J., ed., International Karakoram Project. Cambridge University Press, Cambridge. 51-63

Slater, A. G., Bohn, T. J., McCreight, J. L., et al., 2007. A Mul- timodel Simulation of Pan-Arctic Hydrology. Journal of Geophysical Research, 112: G04S45, doi:10.1029/2006JG 000303

Su, F., Adam, J. C., Bowling, L. C., et al., 2005. Streamflow Simulations of the Terrestrial Arctic Domain. Journal of Geophysical Research, 110: D08112, doi:10.1029/2004 JD005518,

Su, F., Adam, J. C., Trenberth, K. E., et al., 2006. Evaluation of Surface Water Fluxes of the Pan-Arctic Land Region with a Land Surface Model and ERA-40 Reanalysis. Journal of Geophysical Research, 111: D05110, doi:10.1029/2005 JD006387

Wake, C. P., 1989. Glaciochemical Investigations as a Tool to Determine the Spatial Variation of Snow Accumulation in the Central Karakoram, Northern Pakistan. Annals of Glaciology, 13: 279-284

Wang, W., Li, K., Gao, J., 2011. Monitoring Glacial Shrinkage Using Remote Sensing and Site-Observation Method on Southern Slope of Kalik Mountain, Eastern Tian Shan, China. Journal of Earth Science, 22(4): 503-514, doi:10. 1007/s12583-011-0203-8

Wu, L. H., Li, H. L., Wang, L., 2011. Application of a Degree-Day Model for Determination of Mass Balance of Urumqi Glacier No. 1, Eastern Tianshan, China. Journal of Earth Science, 22(4): 470-481, doi:10.1007/s12583011-0201-x

Yatagai, A., Arakawa, O., Kamiguchi, K., et al., 2009. A 44-Year Daily Gridded Precipitation Dataset for Asia Based on a Dense Network of Rain Gauges. SOLA, 5: 137-140, doi:10.2151/sola.2009-035

Zhang, S. Q., Ye, B. S., Liu, S. Y., et al., 2012a. A Modified Monthly Degree-Day Model for Evaluating Glacier Runoff Changes in China. Part I: Model Development. Hydrological Processes, 26(11): 1686-1696, doi:10.1002/ hyp. 8286

Zhang, S. Q., Gao, X., Ye, B. S., et al., 2012b. A Modified Monthly Degree-Day Model for Evaluating Glacier Runoff Changes in China. Part II: Application. Hydrological Processes, 26(11): 1697-1706, doi:10.1002/hyp.8291

Zhao, Q. D., Ye, B. S., Ding, Y. J., et al., 2011. Hydrological Process of a Typical Catchment in Cold Region: Simulation and Analysis. Journal of Gaciology and Geocryology, 33(3): 595-605 (in Chinese with English Abstract) 